\title{
Identification of groundwater prospective zones by using remote sensing and geoelectrical methods in Jharia and Raniganj coalfields, Dhanbad district, Jharkhand state
}

\author{
BASUdeo RAI ${ }^{1, *}$, A TiWARI ${ }^{2}$ and V S DUBEY ${ }^{3}$ \\ ${ }^{1}$ The Indian Planetary Society, 404 Gorai Herumb Building, L T Road, Borivali(W), Mumbai, India. \\ ${ }^{2}$ Professor, Geology Department, B N College, Patna, India. \\ ${ }^{3}$ Professor, Geology Department, Patna University, Patna, India. \\ *e-mail:drbasudeo_rai@yahoo.co.in
}

The Dhanbad district in Jharkhand faces acute water scarcity and is chronically drought-prone. The groundwater resources in the area have not been fully exploited. The present study was undertaken to evaluate the groundwater prospective zones. Landsat-5 Multi Spectral Scanner (MSS) data of band 2 and band 4 and false colour composite (FCC) of band 2, 3, 4 were interpreted visually to differentiate different hydromorphogeological units and to delineate the major trends of lineaments. The different geomorphic features identified are linear ridges, residual hills, and pediplain, buried pediment and dissected pediplain, besides lineaments. The study shows that the pediplain and buried pediments are promising zones for groundwater prospecting. The occurrence and movement of groundwater is restricted to the unconsolidated material, weathered and fractured rocks. For the selection of tube well sites, geoelectrical resistivity investigations have been carried out at the sites, which were found suitable based on hydrogeomorphological and hydrogeological studies. Twenty-six Vertical Electrical Soundings (VES) have been carried out by using Schlumberger electrode configuration, which have brought out 3 to 7 layered sub-surface layers. The resistivity of water-bearing weathered/fractured rocks varies from $120-150 \mathrm{ohm}$. The integrated studies have revealed that the blue colour zones are most promising for groundwater exploration and dug wells may be dug up to depths of $30 \pm 5 \mathrm{~m}$.

\section{Introduction}

Prospective groundwater zones are poorly defined in the hard rock terrain of Jharkhand state. The Dhanbad district in Jharkhand state is chronically drought-prone and faces acute water scarcity both for irrigation and drinking purposes. While the surface water resources in the area are inadequate to meet the local need, the groundwater resources are not explored sufficiently. With the advent of multispectral scanners, groundwater exploration based on surfacial expressions of the terrain has become more effective and viable.
In view of this, the Landsat data were analyzed for hydrogeomorphological study (Tiwari and Rai 1996) for groundwater development in this area. Subsequently ground investigations started geophysically for pinpointing high potential zones. The area under study is a part of the Dhanbad district, Jharkhand state. It lies between latitudes of $23^{\circ} 30^{\prime}$ and $24^{\circ} 0^{\prime}$ North and longitudes of $86^{\circ} 30^{\prime}$ and $87^{\circ} 0^{\prime}$ East and covers an area of $2115 \mathrm{~km}^{2}$ including $654 \mathrm{~km}^{2}$ area of Dhanbad district (figure 1) and table 1. The Damodar and Barakar rivers flow perennially through the area from northwest to southeast. The monsoon is normally

Keywords. Tectonics; remote sensing; lineament; resistivity; geoelectrical methods; groundwater. 


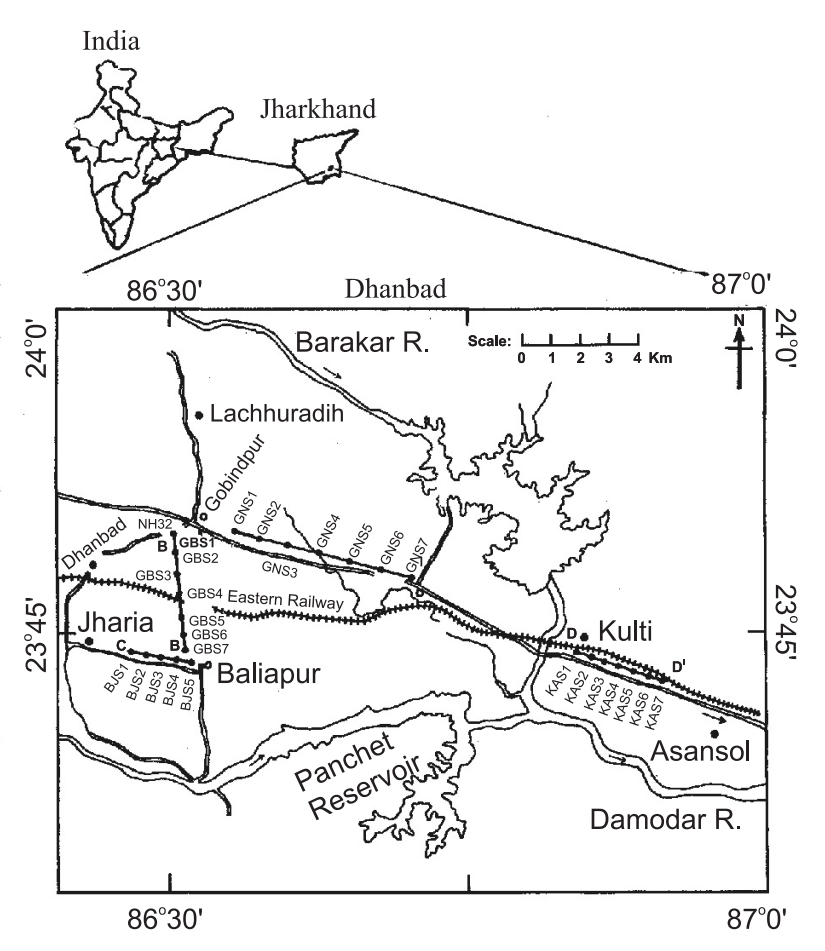

Source : Toposheet No.73I of SOI - parts of Dhanbad, Jharkhand

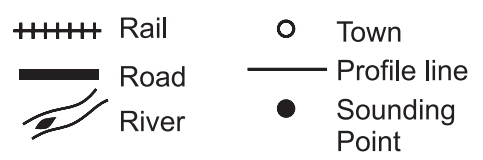

Figure 1. Location map of the study area.

confined to the period from the middle of June to early October. The average annual rainfall in the area is about $1270 \mathrm{~mm}$. The temperature in summer goes up to $40^{\circ} \mathrm{C}$ and in winter comes down to $20^{\circ} \mathrm{C}$.

The rocks of the area belong to the Archaean and Gondwana groups (Fox 1930). The Gondwana rocks occupy the eastern portion of the area while the Archaeans occupy the rest. Lithologically, the Gondwana group consists of sandstone, shale and coal and the Archaeans are comprised of quartzites and gneisses (Sharma and Agrawal 1950; Mehta and Murthy 1957) as shown in figures 2 and 3. The occurrence, origin, movement and chemical constituents of groundwater are dependent on the geologic framework, i.e., lithology, thickness, structures, and permeable, semi-permeable or impermeable nature of the rocks through which it moves. The movement of groundwater is dependent on the permeability of the rocks which in turn, is related to the nature, size and degree of compaction and inter connection of pores, fissures and other rocks interstices. The porosity and permeability of various rocks may depend partly on the rock type and partly on the hydrogeological conditions. Damodar is the major river, which along with several other tributaries drains the area. The generalized drainage pattern of the area is dendritic to sub-dendritic (figure 4).

Hydrological characteristics of the Barakar formations vary from one area to another, depending upon the nature of rocks near the surface. In areas where coarse-grained sandstones are at the top of the surface, the formation acts as a good aquifer. However, if intercalated clays or shale are near the top, the yield of groundwater is very poor, although upper layers are characterised by low resistivity values.

\section{Methodology}

Landsat-5 Multi Spectral Scanner (MSS) data of band 2 and 4 and their false colour composite (band 2, 3 and 4) on 1:250,000 scale were visually interpreted with the help of the characteristic image-interpretation elements like shape, size, tone, texture and pattern. The study area indicates the following hydrogeomorphological features (figure 5). The band 1 and 2 of MSS are in the visible (green and red band, respectively) and band 3 and 4 are in the near-infrared range of spectrum. Band $1(0.45-0.52 \mu \mathrm{m})$ has good water penetration capability and strong vegetation absorbance. Band $2(0.52-0.60 \mu \mathrm{m})$ has very strong vegetation reflectance i.e., vegetation can easily be identified on this band. Band $3(0.63-0.69 \mu \mathrm{m})$ is very much suitable for vegetation. Band $4(0.76-0.90 \mu \mathrm{m})$ near infrared is suitable for water and land mapping. Different landforms are identified on band 2 and band 4 images, for example, hillocks of the area show medium-to-dark gray tone and coarse texture on band 2 and 4 but dark reddish colour on false colour composite with radial drainage pattern. Water body and land contact are very sharply contrasted on black and white images and appear dark blue on FCC. Vegetation and settlements look gray in colour on FCC. Settlements were identified by their regular shape. Weathered rocks show a light tone on Landsat band 2 and 4 and a light gray tone on FCC.

Subsequently, the prospective zones were tested by using Schlumberger array with a maximum half electrode $(\mathrm{AB} / 2)$ distance of $300 \mathrm{~m}$. The array consists of four electrodes arranged symmetrically along a straight line with the outer two for current injecting and the inner two for potential measuring. Spacing between the current electrodes is greater than four times the spacing between the potential electrodes. In each sounding, current electrodes were spread out step by step. Potential electrodes were spread out when the measured potential was lower than $1 \mathrm{mV}$ for available current intensity. Apparent resistivities were calculated in 
Table 1. List of observation points.

\begin{tabular}{|c|c|c|c|c|c|}
\hline $\begin{array}{l}\text { Gobindpur- } \\
\text { Nirsa (A-A') } \\
\text { Sl. no. }\end{array}$ & VES no. & Place & Latitude & Longitude & Spread direction \\
\hline 1 & $\mathrm{GNS}_{1}$ & Dewali Bazar & $20^{\circ} 50^{\prime}$ & $86^{\circ} 34.4^{\prime}$ & NE-SW \\
\hline 2 & $\mathrm{GNS}_{2}$ & Kharkabad & $23^{\circ} 49.7^{\prime}$ & $86^{\circ} 35.88^{\prime}$ & $\mathrm{NE}-\mathrm{SW}$ \\
\hline 3 & $\mathrm{GNS}_{3}$ & Gopalpur & $23^{\circ} 49.4^{\prime}$ & $86^{\circ} 37.35^{\prime}$ & NNE-SSW \\
\hline 4 & $\mathrm{GNS}_{4}$ & Near RBI factory & $23^{\circ} 49.6^{\prime}$ & $86^{\circ} 38.5^{\prime}$ & $\mathrm{NE}-\mathrm{SW}$ \\
\hline 5 & $\mathrm{GNS}_{5}$ & Gopalpur more & $23^{\circ} 48.6^{\prime}$ & $86^{\circ} 40^{\prime}$ & $\mathrm{NE}-\mathrm{SW}$ \\
\hline 6 & $\mathrm{GNS}_{6}$ & $18 \mathrm{~km}$ mile stone & $23^{\circ} 48.37^{\prime}$ & $86^{\circ} 41.3^{\prime}$ & NE-SW \\
\hline 7 & $\mathrm{GNS}_{7}$ & $0.5 \mathrm{~km}$ away from stn. 6 & $23^{\circ} 47.9^{\prime}$ & $86^{\circ} 42.6^{\prime}$ & NNE-SSW \\
\hline \multicolumn{6}{|c|}{ Gobindpur-Baliapur profile B-B' } \\
\hline 8 & $\mathrm{GBS}_{1}$ & Near Culbert & $23^{\circ} 49.5^{\prime}$ & $86^{\circ} 30.28^{\prime}$ & NW-SE \\
\hline 9 & $\mathrm{GBS}_{2}$ & One $\mathrm{km}$ from $\mathrm{stn} .8$ & $23^{\circ} 48.9^{\prime}$ & $86^{\circ} 30.38^{\prime}$ & NW-SE \\
\hline 10 & $\mathrm{GBS}_{3}$ & $2 \mathrm{~km}$ from $\mathrm{stn} .8$ & $23^{\circ} 48.1^{\prime}$ & $86^{\circ} 30.48^{\prime}$ & NW-SE \\
\hline 11 & $\mathrm{GBS}_{4}$ & Pandeydih & $23^{\circ} 47.1^{\prime}$ & $86^{\circ} 30.57^{\prime}$ & NW-SE \\
\hline 12 & $\mathrm{GBS}_{5}$ & Pandeydih 1 & $23^{\circ} 46^{\prime}$ & $86^{\circ} 30.76^{\prime}$ & NW-SE \\
\hline 13 & $\mathrm{GBS}_{6}$ & $1 \mathrm{~km}$ away from $\mathrm{GBS}_{5}$ & $23^{\circ} 45.4^{\prime}$ & $86^{\circ} 30.76^{\prime}$ & NW-SE \\
\hline 14 & $\mathrm{GBS}_{7}$ & $2 \mathrm{~km}$ away from $\mathrm{GBS}_{5}$ & $23^{\circ} 44.5^{\prime}$ & $86^{\circ} 30.98^{\prime}$ & NW-SE \\
\hline \multicolumn{6}{|c|}{ Baliapur-Jharia profile C-C' } \\
\hline 15 & BJS $_{1}$ & Near police station & $23^{\circ} 44.5^{\prime}$ & $86^{\circ} 29.3^{\prime}$ & NE-SW \\
\hline 16 & $\mathrm{BJS}_{2}$ & $1 \mathrm{~km}$ away from BJS $_{1}$ & $23^{\circ} 44.4^{\prime}$ & $86^{\circ} 30.8^{\prime}$ & $\mathrm{NE}-\mathrm{SW}$ \\
\hline 17 & $\mathrm{BJS}_{3}$ & $1.5 \mathrm{~km}$ away from BJS $_{1}$ & $23^{\circ} 44.3^{\prime}$ & $86^{\circ} 30.8^{\prime}$ & NNE-SSW \\
\hline 18 & $\mathrm{BJS}_{4}$ & $2 \mathrm{~km}$ away from BJS $_{1}$ & $23^{\circ} 44.1^{\prime}$ & $86^{\circ} 31.6^{\prime}$ & NE-SW \\
\hline 19 & $\mathrm{BJS}_{5}$ & Near railway track & $23^{\circ} 44.1^{\prime}$ & $86^{\circ} 32.3^{\prime}$ & $\mathrm{NE}-\mathrm{SW}$ \\
\hline \multicolumn{6}{|c|}{ Kulti-Asansole profile D-D' } \\
\hline 20 & $\mathrm{KAS}_{1}$ & Chas road more & $23^{\circ} 44.8^{\prime}$ & $86^{\circ} 50.8^{\prime}$ & NNE-SSW \\
\hline 21 & $\mathrm{KAS}_{2}$ & $1.5 \mathrm{~km}$ away from $\mathrm{KAS}_{1}$ & $23^{\circ} 44.4^{\prime}$ & $86^{\circ} 51.6^{\prime}$ & NNE-SSW \\
\hline 22 & $\mathrm{KAS}_{3}$ & $2.0 \mathrm{~km}$ away from $\mathrm{KAS}_{1}$ & $23^{\circ} 44.1^{\prime}$ & $86^{\circ} 52.3^{\prime}$ & NE-SW \\
\hline 23 & $\mathrm{KAS}_{4}$ & $2.5 \mathrm{~km}$ away from $\mathrm{KAS}_{1}$ & $23^{\circ} 43.9^{\prime}$ & $86^{\circ} 53.4^{\prime}$ & NE-SW \\
\hline 24 & $\mathrm{KAS}_{5}$ & $3.0 \mathrm{~km}$ away from $\mathrm{KAS}_{1}$ & $23^{\circ} 43.7^{\prime}$ & $86^{\circ} 54.1^{\prime}$ & NNE-SSW \\
\hline 25 & $\mathrm{KAS}_{6}$ & $4.0 \mathrm{~km}$ away from $\mathrm{KAS}_{1}$ & $23^{\circ} 43.5^{\prime}$ & $86^{\circ} 54.2^{\prime}$ & NNE-SSW \\
\hline 26 & $\mathrm{KAS}_{7}$ & Barakar & $23^{\circ} 43.3^{\prime}$ & $86^{\circ} 55^{\prime}$ & NE-SW \\
\hline
\end{tabular}

the field for inspecting the data quality. If a distortion in data appeared, measurement was repeated or the current electrode position was changed to improve the quality of data. All the sounding curves were interpreted by using automatic 1-D inversion method given by Zohdy (1974b). This method is fundamentally a least-squares method that has been widely used in resistivity data interpretation. The key features are that the number of layers is equal to the number of data points and that the layer thicknesses are equal on a log scale. The models may change radically if a data point is added or subtracted.

\section{Results and discussion}

\subsection{Remote sensing studies}

The broad categories of landforms and their distribution/extent as interpreted from Landsat imageries and confirmed on the ground are presented in figure 5. Hydromorphogeological units identified are linear ridge (dyke), residual hills, pediplain, buried pediment, dissected buried pediment and lineament. A detailed description of these features identified in the area and the groundwater prospects in each of them, are given below.

\subsubsection{Linear ridges (dykes)}

These are sheet like bodies of igneous rock which are discordant, i.e., cut across the bedding of structural plains of host rocks. Dhangi ridge is a prominent linear ridge in the study area near Gobindpur. These are dolerite dykes and appear in a dark tone on Landsat imageries. They occur in linear, narrow, low-lying relief and are barren. The groundwater prospects in this geomorphic unit are poor; but in the study area these dykes act as subsurface barriers for groundwater movement within the 




Figure 2. Geological map of the Jharia coalfield.

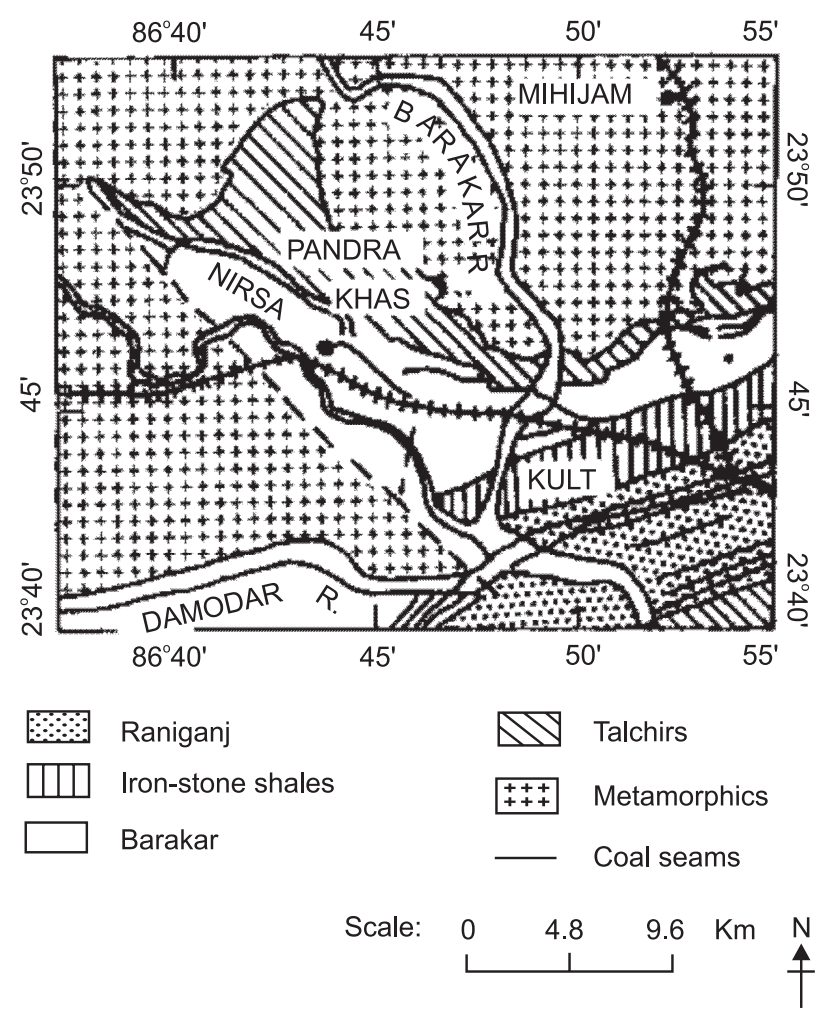

Figure 3. Geological map of the northwestern part of Raniganj coalfield.

weathered mantle making the prospect of groundwater good. The sounding point GBS5 indicates that second and third layer resistivity are $86 \mathrm{ohm} \mathrm{m}$ and $124 \mathrm{ohm} \mathrm{m}$, which show that the area has a very high potential for groundwater and this is due to the effect of dykes.

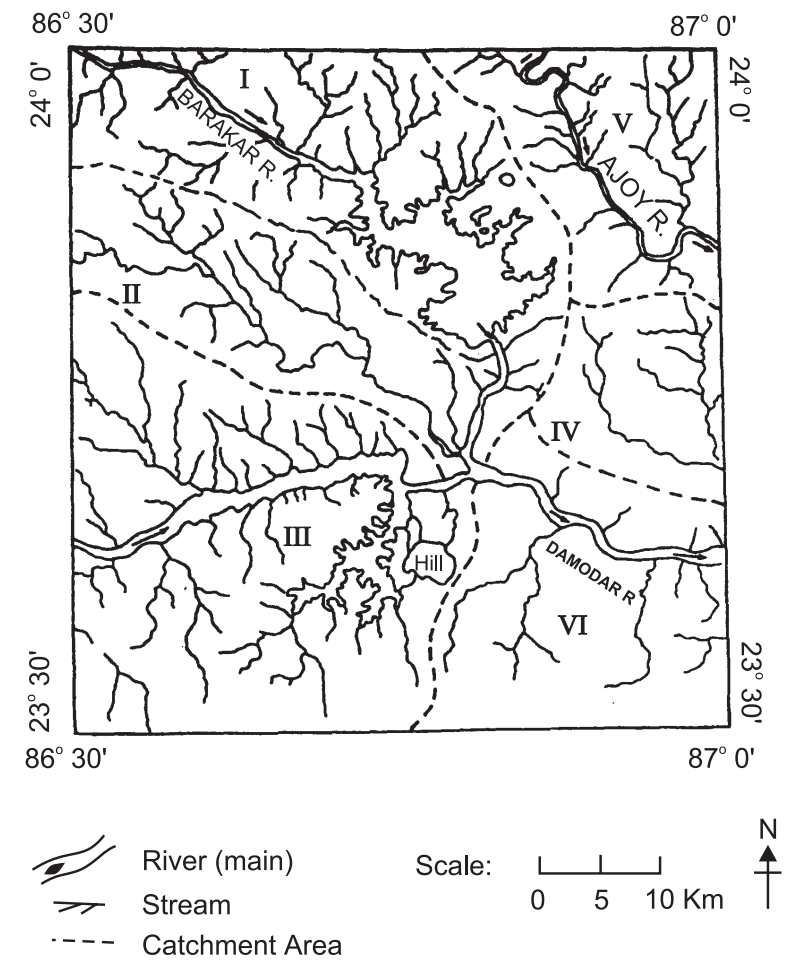

Figure 4. Drainage map of the study area based on Landsat imagery and Toposheet 73/I.

\subsubsection{Residual hills}

Residual hills are more resistant formations standing out prominently due to differential erosion and weathering. On Landsat imagery (MSS band 2, 4 and FCC) residual hills appear as isolated hills or in a continuous chain of hillocks characterised by medium to dark gray tone and coarse texture in black and white images, and dark reddish colour in false colour composite with radial drainage pattern (Gupta 1980). This geomorphic unit lies north of Gobindpur, panchet reservoir and Maithan reservoir (figure 5). Due to the steep slope most of the rain water is washed off immediately without much infiltration and hence the groundwater prospects in this unit are poor.

\subsubsection{Pediplain}

The pediplain and dissected pediplain with sedimentary outcrops (Gondwana formation) are found in the eastern part of the area. This is formed as a result of weathering under arid and semi-arid conditions, representing the end stage of cyclic erosion (Knig 1950; Sparks 1960). These have medium-todark tone on black and white imagery and gray tone on FCC (Ghose 1993). Groundwater prospects in this unit appear to be good due to moderately thick (15-20 m) weathered material (Prakash and Mishra 1993). This unit shows a light tone on 
$86^{\circ} 30^{\prime}$

$87^{\circ} 0^{\prime}$

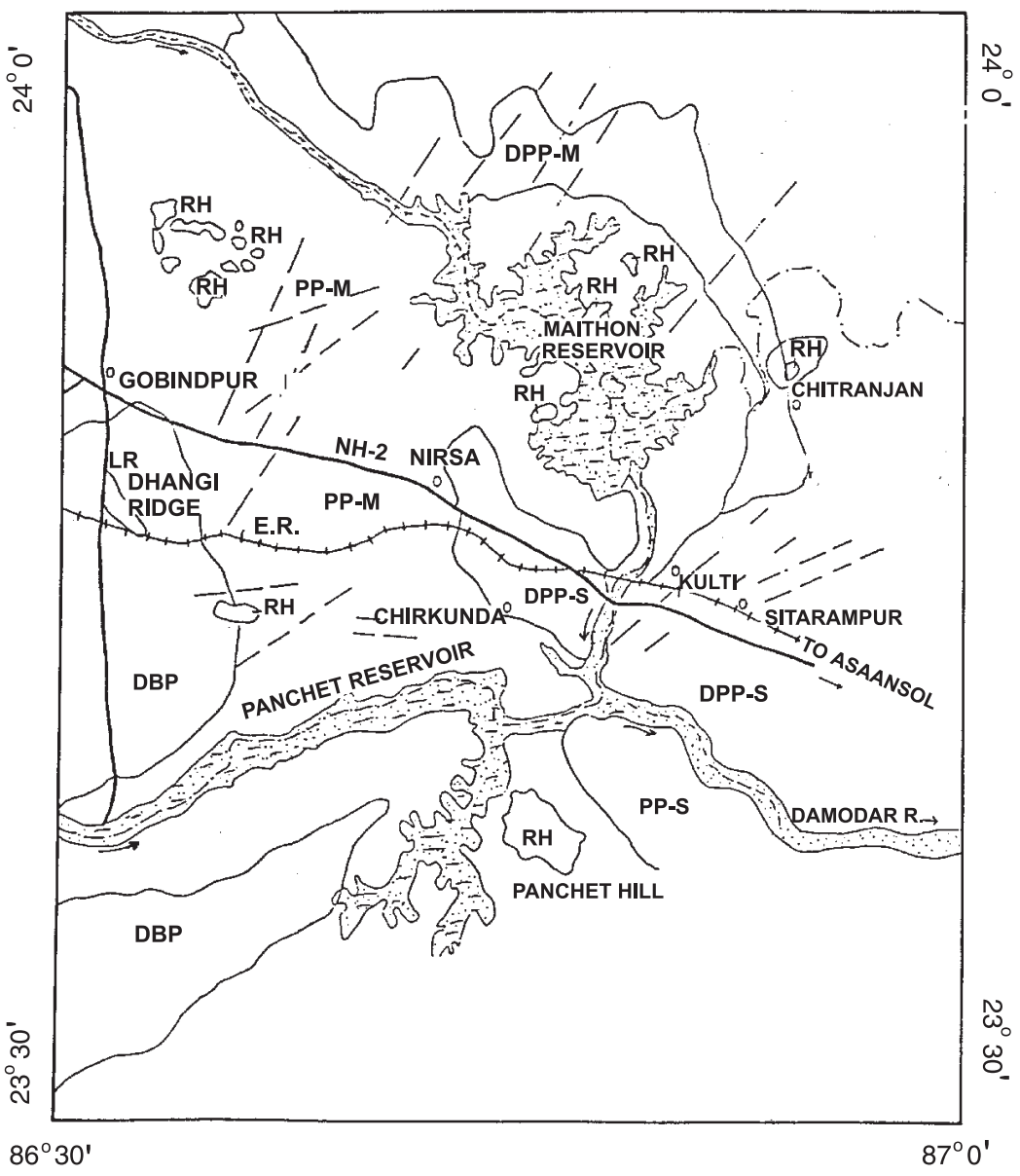

\section{LEGEND}

$\begin{array}{cc}\text { MAP } & \text { GEOMORPHIC } \\ \text { SYMBOL } & \text { UNIT }\end{array}$

\begin{tabular}{ll} 
LR & Linear Ridge \\
RH & Residual Hill \\
PP-S & $\begin{array}{l}\text { Pediplain } \\
\text { (Shallow) }\end{array}$ \\
DPP-S & $\begin{array}{l}\text { Dissected } \\
\text { pediplain (Shallow) }\end{array}$ \\
PP-M & $\begin{array}{l}\text { Pediplain } \\
\text { (Moderate) }\end{array}$ \\
DPP-M & $\begin{array}{l}\text { Dissected } \\
\text { pediplain (Moderate) }\end{array}$ \\
DBP & $\begin{array}{l}\text { Dissected burried } \\
\text { pediment }\end{array}$ \\
\hline
\end{tabular}

Lineaments

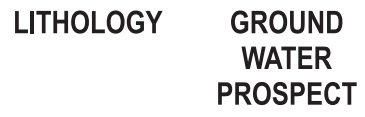

$\begin{array}{ll}\text {--- } & \text { Poor } \\ \begin{array}{ll}\text { Sedimentary } \\ \text { outcrop }\end{array} & \begin{array}{l}\text { Poor to } \\ \text { moderate }\end{array} \\ \begin{array}{l}\text { Sedimentary } \\ \text { outcrop }\end{array} & \begin{array}{l}\text { Poor to } \\ \text { moderate }\end{array} \\ \begin{array}{l}\text { Metamorphic } \\ \text { outcrop }\end{array} & \begin{array}{l}\text { Moderate } \\ \text { to good }\end{array} \\ \begin{array}{l}\text { Metamorphic } \\ \text { outcrop }\end{array} & \begin{array}{l}\text { Moderate } \\ \text { to good }\end{array} \\ \begin{array}{l}\text { Metamorphic } \\ \text { outcrop }\end{array} & \text { Good } \\ & \text { Good }\end{array}$

Settlement

Road

River

Waterbodies

Railway line

State Boundary

District Boundary

Scale : \begin{tabular}{lllll}
2.5 & 0 & 2.5 & 5 & 7.5 \\
\hline
\end{tabular}

Figure 5. Hydromorphogeological map of the study area. 
Landsat black and white imagery and light gray tone on FCC.

\subsubsection{Buried pediment and dissected buried pediment}

These landforms are erosional geomorphic features and have developed by the process of weathering of the hills, having a thin veneer of deposition adjacent to high relief outcrops. If the pediments are covered by alluvium or weathered material, they are termed buried pediments. These buried pediments are found in the western part of the study area (figure 5) and have a medium tone on black and white imagery and a very light gray tone on FCC. The groundwater prospects are good because thickness is more than 20 meters.

\subsubsection{Lineaments}

In the area $\left(23^{\circ} 45^{\prime}-23^{\circ} 48^{\prime} \mathrm{N}\right.$ and $\left.86^{\circ} 45^{\prime}-87^{\circ} 0^{\prime} \mathrm{E}\right)$ lineaments (NE-SW) representing contact of Gondwana formation and granite gneiss terrain of Chhotanagpur are deciphered. The criss-cross lineaments with NE-SW strike $\left(23^{\circ} 45^{\prime}-23^{\circ} 55^{\prime} \mathrm{N}\right.$ and $86^{\circ} 35^{\prime}-86^{\circ} 40^{\prime} \mathrm{E}$ ) due to the fractures in the bedrock was also observed in the area. Groundwater prospect in this region is good due to the intersection of the above lineaments (Tiwari 1993).

\subsection{Geophysical studies}

Based on remote sensing studies and hydrogeological conditions, 26 locations as shown in figure 1 and table 1 were selected to carry out the geoelectrical resistivity survey (Keller and Frischnecht 1966; Kunetz 1966; Orellana and Mooney 1966; Bhattacharya and Patra 1968; Verma et al 1980). Geoelectrical investigations were conducted for identification of the nature of subsurface formations, estimation of the thickness of various litho units and demarcation of their lateral and vertical extensions.

The sounding curves in the area in general are of $\mathrm{A}, \mathrm{H}$ and $\mathrm{HA}$ types representing 3 to 7 layer subsurface set-up. The typical sounding curves of the study area are shown in figure 6 .

Resistivity contour map of the Gobindpur-Nirsa $\left(\mathrm{A}-\mathrm{A}^{\prime}\right)$ profile, Gobindpur-Baliapur (B-B') profile, Baliapur-Jharia $\left(\mathrm{C}-\mathrm{C}^{\prime}\right)$ profile and Kulti-Asansol (D-D') profile shown in figure 1, was prepared using potential layer resistivity value and is shown in figure $7(\mathrm{a} \mathrm{b} \mathrm{c} \mathrm{d})$. It indicates predominance of low resistivity (less than $40 \mathrm{ohm} \mathrm{m}$ ) soil in the western most part of the profile $\mathrm{A}-\mathrm{A}^{\prime}$ (figure $7 \mathrm{a}$ ).

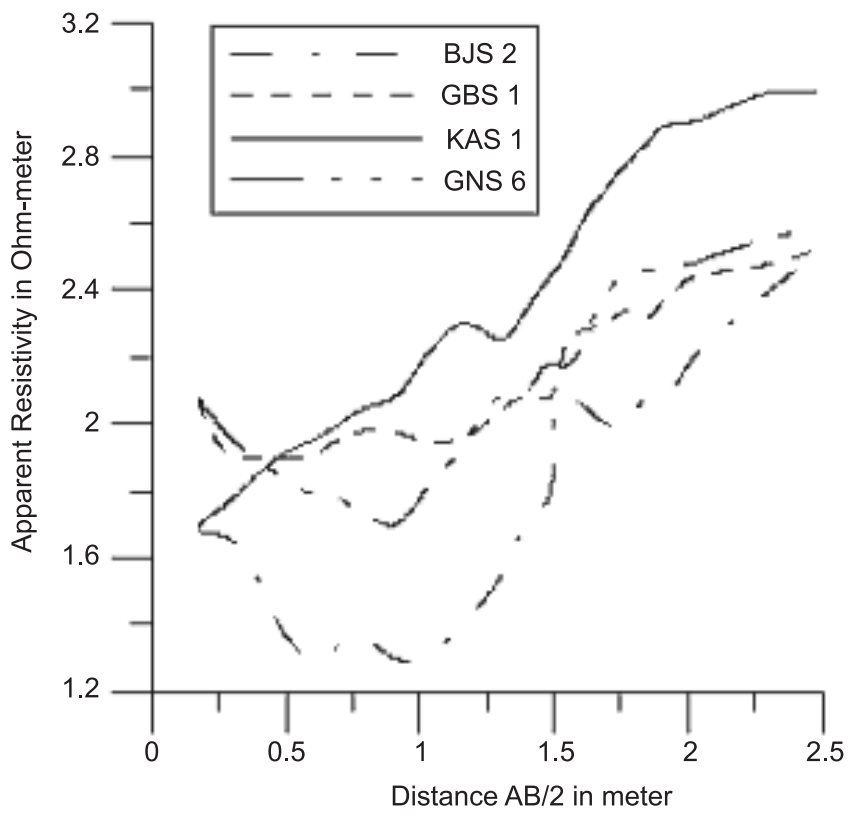

Figure 6. Representative apparent resistivity curve of the study area.

The middle portion shown in pink colour (figure 7a) are less granular due to intercalation of clay. Based on the surface resistivity contour map (figure 7a), the sounding points GNS5, GNS6 and GNS7 are placed in category one. GNS3 and GNS4 are placed in the second category of preference and GNS1 placed in the third category.

Similarly resistivity contour map (figure $7 \mathrm{~b}$ ) of profile B-B' indicates granular (blue colour) due to weathered sand. On the basis of the resistivity map sounding points GBS5 is placed in category one and the site is recommended for shallow bore well. Other sites GBS1 to GBS4 are placed in category three due to very high resistivity and these sites are recommended for dugwell. Dugwells may be dug up to depths of $20 \pm 2 \mathrm{~m}$ bgl., based on layer resistivity of sounding GBS1, GBS2 data.

Surface resistivity contour map of profile $\mathrm{C}-\mathrm{C}$ ' (figure 7c) indicates that the blue colour zone is more granular than the green colour zone and the red colour zone is less granular due to the presence of a less permeable layer. But this (green colour) zone is saturated. On the basis of this map, the sounding point BJS2 is in the first category and BJS1, BJS3, BJS4 are in the second category. BJS5 is also equivalent to BJS1, BJS4 and BJS5. On the basis of figure 7(c), the site BJS2 is most suitable for shallow bore well. This area is mixed with clay or shale having a resistivity of 100 to $115 \mathrm{ohm}$ m. Coloured portion shows fresh water aquifer zone suitable for dugwell or shallow tube well. In this sounding point, BJS2, (figure 7c) granular zone can be found in the western side, the other area having very high resistivity due to the coal-seams. 

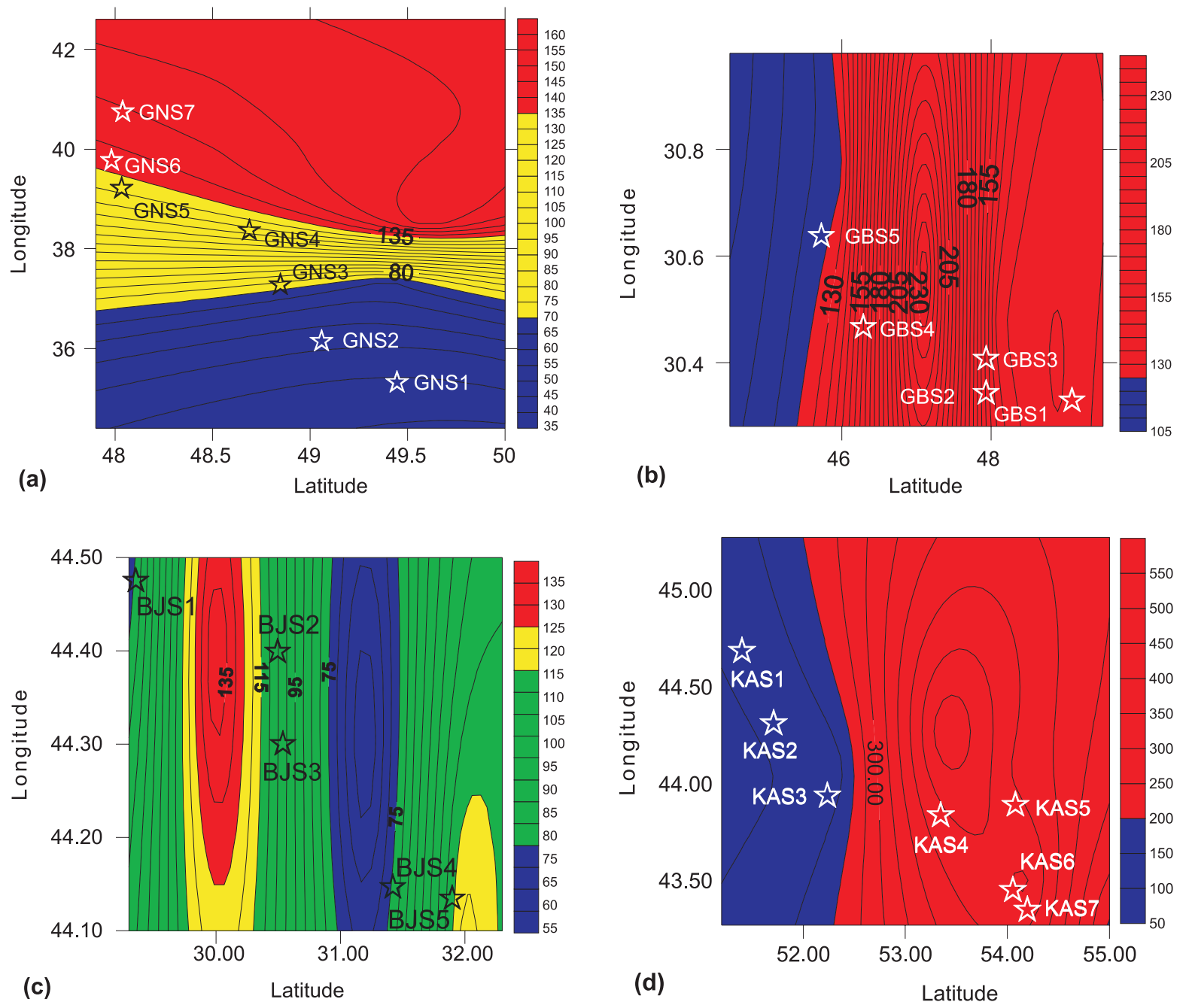

Figure 7. (a) Area of fresh groundwater availability up to 15 to $20 \mathrm{~m}$ below ground level (bgl) and beyond. Based on VES interpretation (blue colour indicates granular zone, yellow colour indicates less granular and red colour indicates granular zone having higher resistivity). (b) Areas of fresh groundwater availability up to $15-20 \mathrm{~m}$ below ground level (bgl) and beyond (blue colour indicates granular zone and red colour indicates high resistive zone). (c) Area of fresh groundwater availability up to 15-20 m below ground level (bgl) and beyond. Based on VES interpretation (blue colour indicates granular zone, green colour indicates less granular zone, pink colour more granular and red colour indicates most granular zone). (d) Area of fresh groundwater availability up to 15-20 m below ground level (bgl) and beyond. Based on VES interpretation (blue colour is more granular zone and red indicates resistive zone).

Resistivity contour map of profile D-D' (figure $7 \mathrm{~d}$ ) is shown in the blue colour portion $(50-200 \mathrm{ohmm})$. This zone is suitable for fresh water. The red colour zones have very high resistivity. On the basis of resistivity contour map the sounding point of profile D-D', KAS1, KAS2, and KAS3 indicate granular zone.

\section{Conclusions}

The integrated remote sensing, hydrogeological and electrical resistivity investigations reveal that the study area is very complex and in general, does not hold high potential for groundwater development through deep tube wells/bore wells. Based on the hydrogeomorphological mapping and resistivity data, the following broad conclusions can be drawn:

- The present study brings out the close relationship among the geomorphic, hydrogeologic and geophysical parameters of groundwater. The results of resistivity survey conducted in the area have revealed that out of $26 \mathrm{VES}$, only $15 \mathrm{VES}$ have been identified as showing good potential, and 8 VES fair to good, whereas the rest showed poor potential.

- Good potential zones have been located in VES No. GNS3, GNS4, GNS5, GBS4, BJS2, BJS1, BJS3, BJS4, BJS5 and KAS1.

- From the correlation of the hydromorphological map, bed rock topography map and the apparent 
resistivity contour map, it has been inferred that the groundwater of the present area may be classified into the following categories in the order of decreasing potential zones.

The groundwater potential zone map (figure 7) was compared with the existing dug well in the study area. The comparison showed that the groundwater potential zones are in agreement with the dug well data. Three groundwater potential zones (high in category first, moderate in category second and low in category third) have been identified in the study area. The pediplain and dissected pediplain with sedimentary outcrops have good prospects of groundwater due to moderately thick weathered material. Similarly buried pediment and dissected buried pediment and criss-cross lineaments have good prospects of groundwater. The blue colour zone of figure 7 is placed in category one, i.e., high potential zone, the pink colour zone of figure 7 is placed in the second category and the green colour zone of figure 7 is placed in the second category though it has more potential i.e., moderate zone than the pink colour zone. The red colour zone of figure 7 is placed in the category three, i.e., low potential zone.

\section{Acknowledgements}

Authors are grateful to the Head of the Geology Department, B.N. College, Patna, for providing all facilities to carry out this research work. Corresponding author is thankful to Prof V Subramaniam (retd.), Department of Earth Science, Indian Institute of Technology, Powai, Mumbai, Dr J J Rawal, President of The Indian Planetary Society, for fruitful discussions and encouragement. Last but not least, the corresponding author is grateful to the anonymous reviewer for critically examining the manuscript, and to the Associate Editor, for his efforts throughout this publication.

\section{References}

Bhattacharya P K and Patra H P 1968 Direct current electrical sounding; (Elsevier, Amsterdam).

Fox C S 1930 The Jharia coalfield; Mem. GSI 56(1) 225.

Ghose R 1993 Remote sensing for analysis of groundwater availability in an area with long unplanned mining history; J. Indian Soc. Remote Sensing 21(3) 119-126.

Gupta A 1980 Correlation of Landsat and airborne magnetic anomaly data of a part of the Bihar mica belt; Proc. Symp. Remote Sensing in subsurface exploration, held on 25 Oct., Bangalore, India, pp. 23-30.

Knig L C 1950 The study of the worlds plain lands. A new approach in geomorphology; Q. Geol. Soc. London 106 101-103.

Keller G V and Frischnecht F C 1966 Electrical methods in Geophysical prospecting; (Pergamon, Oxford).

Kunetz G 1966 Principles of Direct current Resistivity prospecting; (Gebruder Borntraeger, Berlin).

Mehta D R S and Murthy B R L 1957 Revision of the geology of coal resources of the Jharia coalfield; Mem. GSI 84(2) 113.

Orellana E and Mooney H M 1966 Master tables and curves for vertical electrical sounding over layered structures, (Intercientia, Madrid).

Prakash S Ravi and Mishra D 1993 Identification of groundwater prospective zones by using Remote Sensing and geoelectrical methods in and around Saidnagar area. Dakor block, Jalaun district, U.P; J. Indian Soc. Remote Sensing 21(4) 217-227.

Sharma N L and Agrawal Y K 1950 A note on the rapakivi structure in the epidiorite and injection gneiss of Dhanbad area. Q.J.G. Min. Met. Soc. India 22 11-13.

Sparks B W 1960 Landform in arid and semi-arid climates; Geomorphology 2nd edn, (Longman Group Ltd.), pp. $335-341$.

Tiwari O N 1993 Lineament identification for groundwater drilling in a hard rock terrain of Sirohi district, Western Rajasthan; J. Indian Soc. Remote Sensing 21(1) $13-19$.

Tiwari A and Rai B 1996 Hydromorphological Mapping for groundwater prospecting using Landsat-MSS images - A case study of part of Dhanbad district, Bihar; J. Indian Soc. Remote Sensing 24(4) 281-285.

Verma R K, Rao M K and Rao C V 1980 Resistivity investigations for groundwater in metamorphic area near Dhanbad, India; Ground Water 18 46-55.

Zohdy A A R 1974b A computer program for the calculation of Schlumberger curves by convolution, U.S. Geological Survey report USGS-GD-74-010, U.S Department of Commerce, NT IS, (Springfield, VA). 